\title{
Acute myocarditis induced by dosage increment of methylphenidate in an adolescent patient
}

\section{Genç erişkin hastada metilfenidat doz artışına bağlı gelişen akut miyokardit}

\author{
Osman Betonn ${ }^{1}$, Recep Kurt' ${ }^{1}$, Hakan Güneş ${ }^{2}$, Hakkı Kaya ${ }^{1}$, Mehmet Birhan Yılmaz ${ }^{1}$
}

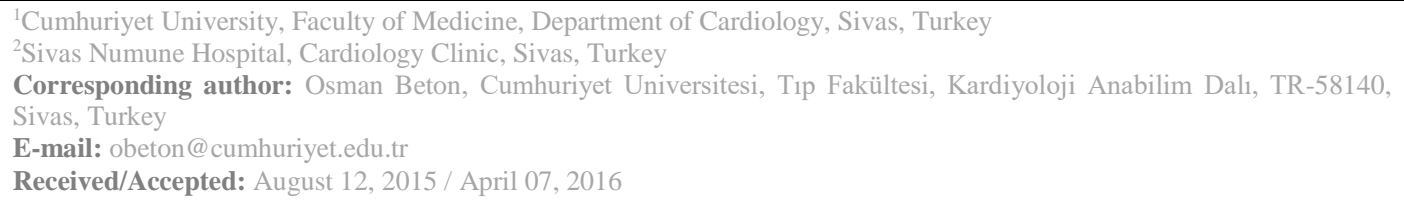

\section{SUMMARY}

Attention deficit-hyperactivity disorder (ADHD) is one of the most common psychiatric disorders seen in children and adolescents. ADHD is increasingly diagnosed and treated nowadays. Methylphenidate is a potent psychostimulant that exerts its effects by increasing dopamine and norepinephrine levels in synapses. It is a widely used medication for treatment of ADHD in children and adolescents. Although not well-established, a causal relationship between treatment of ADHD and development of cardiomyopathy has been suggested. However, this suggestion was supported by the normalization or improvement in cardiac function and functional class after cessation of anti-ADHD medications in patients suffering from cardiomyopathy related to antiADHD medications. In this case report, we describe a case of 14-year-old male patient who developed acute myocarditis due to the dose increment of methylphenidate. The patient completely recovered after discontinuation of methylphenidate. Cardiovascular monitoring of patients on methylphenidate treatment should be an important task for psychiatrists, general practitioners and cardiologists.

Keywords: Attention deficit-hyperactivity disorder, methylphenidate, acute myocarditis

\section{ÖZET}

Dikkat eksikliği-hiperaktivite bozukluğu (DEHB), çocuk ve gençlerde en çok karşılaşılan psikiyatrik hastalıklardan biridir. DEHB tanısı ve tedavisi bu günlerde giderek artmaktadır. Metilfenidat, sinapslardaki dopamin ve norepinefrin düzeylerini arttırarak etkisini gösteren, güçlü bir psikostimulan ajandır. Çocuk ve gençlerde DEHB tedavisinde yaygın olarak kullanılan bir ilaçtır. İyice anlaşılmamış olmasına rağmen, DEHB tedavisi ve kardiyomiyopati gelişimi arasında nedensel bir ilişki öne sürülmüştür. Fakat bu nedensel ilişki, anti-DEHB ilaçlarına bağl1 kardiyomyopati gelişen hastalarda, anti-DEHB ilaçların kesildikten sonra kalp fonksiyonu ve fonksiyonel sınıfın düzelmesi veya normale dönmesi ile desteklenmektedir. Bu olgu sunumunda, metilfenidat doz artışına bağlı akut miyokardit gelişen 14 yaşında bir erkek hastayı betimledik. Hasta, medilfenidat kesilmesinden sonra tamamen düzeldi. Metilfenidat tedavisi alan hastaların kardiyovasküler yönden izlenmesi, psikiyatristler, pratisyen hekimler ve kardiyologlar için önemli bir görev olmalıdır.

Anahtar sözcükler: Dikkat eksikliği - hiperaktivite bozukluğu, metilfenidat, akut miyokardit 


\section{INTRODUCTION}

Attention deficit-hyperactivity disorder (ADHD), the most common neurobehavioral disorder of childhood, is characterized by developmentally inappropriate levels of hyperactivity, inattention, and impulsivity ${ }^{1}$. The vast increase in the diagnosis of ADHD and the frequency of treatment for the condition in children and adolescents is not specific to develped countries, but is also true for developing countries. Medications commonly used in treatment of ADHD may be associated with cardiovascular risk, but the degree of risk and the types of cardiac events are insufficiently investigated. Several cases of methylphenidate-induced cardiomyopathy, including patients of 17-20 years of age, 25 two cases of methylphenidate induced acute myocarditis in patients of 17 and 18 years of age 5, 6 and several cases of acute myocardial infarction possibly due to methylphenidate $^{7-9}$, have been reported. A 2006 United States Food and Drug Administration report ordered a black box warning placed on drugs used in treatment of ADHD due to various cardiovascular side effects, including cardiomyopathy ${ }^{10}$. However, two recent, large scale trials found no evidence of a direct link between ADHD medications and cardiovascular risk in children and young adults ${ }^{11,} 12$. Herein, we report the case of a male adolescent who developed acute myocarditis after increasing the dose of his methylphenidate.

\section{CASE REPORT}

A previously healthy 14-year-old male with a past medical history of ADHD presented to emergency department with the complaints of crushing chest pain, dyspnea and sweating, which had been present for four days. He reported that his chest pain and dyspnea were initially mild, but increased gradually, and became severe and intolerable which made him apply to our emergency department. His ADHD was diagnosed three months ago. Psychotherapy, education and training therapy were initiated, but because of unsatisfactory response, he was started on methylphenidate (Concerta $\AA$ ) $18 \mathrm{mg}$ daily a month prior. He had a partial response to this drug, so the dose of methylphenidate was increased to $36 \mathrm{mg}$ daily six days prior. He denied tobacco, alcohol or illicit drug use and family history was unremarkable. He denied any upper respiratory tract infections in the preceding weeks. On admission, his temperature was $37.6^{\circ} \mathrm{C}$, blood pressure was $120 / 80 \mathrm{mmHg}$, with a pulse of $90 \mathrm{bpm}$, a respiratory rate of 18 per minute, and an oxygen saturation of 98\% on room air. Cardiac examination revealed an irregular rhythm in the absence of murmurs. All other system examinations were within normal limits. Upon arrival to emergency department, an electrocardiogram (ECG) revealed ventricular bigeminy with an underlying sinus rhythm (Figure 1). Chest X-ray was normal with no consolidations or cardiomegaly. Arterial blood gas analyses and D-Dimer test were normal. White blood cell counts and hemoglobin level were in normal range. Urine test was normal. His initial creatinine kinase $(\mathrm{CK})$, creatinine kinase $\mathrm{MB}$ fraction (CK-MB) and troponin I levels were $950 \mathrm{U} / \mathrm{L}, 80$ $\mathrm{U} / \mathrm{L}$ and $6.29 \mathrm{ng} / \mathrm{ml}$, respectively. Initial levels were peak values for cardiac markers. C-reactive protein level was 24.2 $\mathrm{mg} / \mathrm{l}$ with sedimentation rate of $14 \mathrm{~mm} / \mathrm{h}$. $\mathrm{He}$ was given aspirin and transferred to CCU.

Echocardiography revealed global mild hypokinesis with a left ventricular ejection fraction (EF) of 50\% (without segmental or regional wall motion abnormality). No pericardial effusion was detected. However, his EF was found to be $65 \%$ in a prior echocardiographic evaluation. Thyroid function tests, immunological markers (ANA, ANCA, RF), and electrolytes were normal. Bacterial cultures and hepatitis serologies were negative. Methylphenidate was discontinued following hospitalization. Coronary angiography showed normal coronary arteries and the patient did not develop decompensated heart failure. Eight days after hospitalization, CK, CK-MB, troponin I and CRP levels returned to normal values and the patient had complete recovery. Control echocardiography performed before discharge showed normal left ventricular systolic function 
with $\mathrm{EF}$ of $60 \%$. He was diagnosed with acute myocarditis and discharged on metoprolol and ramipril with plans for cardiology follow-up and repeat echocardiography in one month.

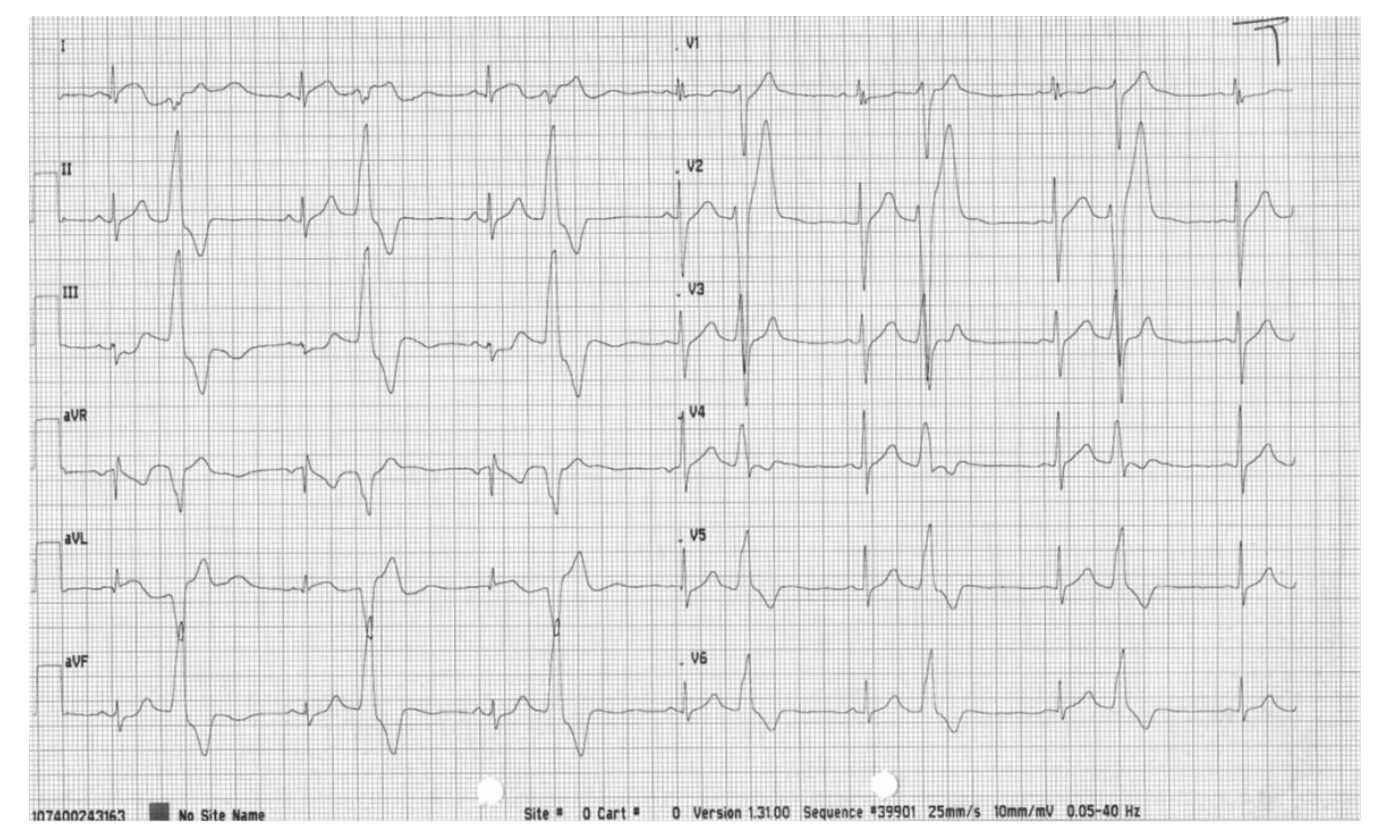

Figure 1: Admission ECG which demonstrated ventricular bigeminy.

\section{DISCUSSION}

We described a patient with myocarditis secondary to drug treatment with methylphenidate soon after dose increment. The evidence supporting the etiologic relationship with methylphenidate included significant improvement after cessation of drug, absence of other etiological factors of myocarditis, and the temporal relationship between dose increment and the complaints. Although little is known about the cardiac effects of methylphenidate, the explanation may lie in the direct effects of catecholamines on cardiac myocytes, acute inflammatory response and endothelial injury $^{13,14}$.

Amphetamine analoges and several other psychotropic drugs cause norepinephrine release and increase its levels at the nerve terminal, an effect which was thought to be only central in nature ${ }^{15}$. Chronic sympathetic activation causes impaired beta adrenoreceptor mediated inotropic response of the heart, leading to myocyte apoptosis and impaired systolic functions of left ventricle ${ }^{16}$. The mechanism by which central nervous system activation causes cardiac side effects is still unclear, but scientific data indicated that stimulation of catecholaminergic system in frontal lobes caused a reflex increase in cardiac diastolic pressure ${ }^{15}, 16$. These two theories might be potential mechanisms in this setting. Moreover, norepinephrine sensitivity exhibits variations between individuals, thus one cannot expect quick and uniform reactions in all patients ${ }^{17}$. The differential sensitivity to these drugs can also in part be explained by different genetic backgrounds of individuals ${ }^{18,19}$.

Methylphenidate can also act as a trigger for acute inflammatory response. Similarly, patients who use cocaine have five times increased risk of myocarditis, which is caused by the microvascular injury ${ }^{13}$. Cocaine can directly affect myocardial muscle by causing acute deteriorations in systolic and diastolic function, as well as alterations in calcium transport in myocytes ${ }^{13}$. The mechanisms underlying these effects are unknown, but may involve catecholamine-mediated increases in lymphocyte and natural killer cell activity ${ }^{13}$. This inflammatory response may exert cytotoxic effect on the myocardium. Methylphenidate may have a 
similar mechanism of action leading myocarditis. In our case, elevated CRP level may be explained by the inflammatory response. Sympathomimetic drugs, including amphetamines and cocaine can cause AMP-induced cardiac injury which includes coronary spasm, prothrombotic state, and accelerated atherosclerosis due to endothelial injury ${ }^{14}$. Methylphenidate-induced myocarditis may also be caused by endothelial impairment and disturbance of microcirculation in addition to direct injury to cardiac myocytes. Methylphenidate effect on endothelial function should be further investigated in order to understand the underlying mechanisms.

Stimulants are usually titrated until there is optimal symptom reduction or significant stimulant-related side effects appear. Mild side effects are commonly reported in children who take stimulant medications, and changes in timing and dosage often result in improvement ${ }^{20}$. A question arises whether dose increment could explain the clinical progression observed in our case. It was shown that methylphenidate had dose-related effect on dopaminergic system to increase heart rhythm and cardiac contraction, which can potentially explain degenerative ultrastructural changes in mitochondrial path when given at high doses to rats ${ }^{21}$. However, only heart rate and blood pressure effects were demonstrated in clinical trials at high $\operatorname{doses}^{20,22}$.

The prevalence of ADHD has increased substantially which may in part be due to establishment of better diagnostic criteria and increased awareness. Current estimated prevalence among children of 218 years of age varies greatly, depending on the diagnostic criteria used and the population studied ${ }^{13}$. It was long thought that ADHD occurred only in children, but 30 to 70 percent of children with ADHD had residual symptoms as adults, and the prevalence of ADHD or ADHD symptoms in adults was $1-7 \%{ }^{14}$. Stimulants (mainly amphetamines and methylphenidate) have been shown in studies to improve symptoms among children and adults, especially in short term, an affect more predominant in children ${ }^{13,}{ }^{14}$. These findings bring up the questions regarding the risks of these drugs. Stimulants have sympathomimetic effects, increase blood pressure and heart rate, and may theoretically increase cardiovascular risk.10 FDA approved these medications, but included a "black box" warning 10 due to potential risks for coronary artery disease, heart failure and fatal arrhythmias. However, large scale studies suggested that ADHD medications did not actually increase the risk of several types of cardiovascular events. Cooper, et al. studied patients between 2-24 years of age, with 2.5 million person years of follow up, of which nearly 400000 people used antiADHD medications, and there was no increased risk of sudden cardiac death, heart attack or stroke ${ }^{13,14}$. Habel, et al. ${ }^{13,14}$ reported that among adults with 800,000 person years of follow up, of which over 100000 people used anti-ADHD medications, there was no increased risk for adverse cardiac events and stroke.A small study suggested that the risk of sudden cardiac death or arrhythmia may be increased but the causal relationship was still not fully clarified ${ }^{13,14}$.

Case reports should be taken as important warnings $^{2-9}$. Although they cannot influence the indications and contraindications per se, they point to the importance of careful monitoring. The screening and monitoring which has been proposed is reasonable. The possible causal relationship attributable to adrenergic effects can in part be monitored easily by blood pressure and heart rate recordings. In line with the increased use of anti-ADHD medications, this monitoring is of particular importance for psychiatrists, primary care and consultant cardiologists.

In conclusion; acute myocarditis, myocardial infraction and dilated cardiomyopathy are adverse cardiac events observed in some patients with methylphenidate. Causative link between methylphenidate use and the development of myocardial pathology is still not known. Additionally, determining the patients at risk for myocardial pathology while on methylphenidate should be a future task to further utilize individual treatment options. 
Further studies are warranted to delineate pathophysiological link, patients under risk and define treatment options.

\section{REFERENCES}

1. Vetter VL, Elia J, Erickson C, et al. Cardiovascular monitoring of children and adolescents with heart disease receiving medications for attention deficit/hyperactivity disorder: a scientific statement from the American Heart Association Council on Cardiovascular Disease in the Young Congenital Cardiac Defects Committee and the Council on Cardiovascular Nursing. Circulation 2008; 117(18):240723.

2. Nymark TB, Hovland A, Bjørnstad $\mathrm{H}$, et al. A young man with acute dilated cardiomyopathy associated with methylphenidate. Vasc Health Risk Manag 2008; 4(2):477-9.

3. Tølløfsrud C, Hoel T. A young man with acute dilated cardiomyopathy. Tidsskr Nor Laegeforen 2006; 126(10):1338-9.

4. Daly MW, Custer G, McLeay PD. Cardiac arrest with pulseless electrical activity associated with methylphenidate in an adolescent with a normal baseline echocardiogram. Pharmacotherapy 2008; 28(11):1408-12.

5. Wikström G, Kvidal P, Hagström E. Life-threatening heart failure caused by ADHD medication. Five case reports described. Lakartidningen 2012;109(45):2016-8.

6. Dadfarmay S, Dixon J. A case of acute cardiomyopathy and pericarditis associated with methylphenidate. Cardiovasc Toxicol 2009; 9(1):49-52.

7. Thompson J, Thompson JR. Acute myocardial infarction related to methylphenidate for adult attention deficit disorder. J Emerg Med 2010;38(1):18-21

8. Ruwald MH, Ruwald AC, Tønder $\mathrm{N}$. Methylphenidate induced ST elevation acute myocardial infarction. Ugeskr Laeger 2012;
174(10):647-8.

9. George AK, Kunwar AR, Awasthi A. Acute myocardial infarction in a young male on methylphenidate, bupropion, and erythromycin. J Child Adolesc Psychopharmacol 2005; 15(4):693-5.

10. Nissen SE. ADHD drugs and cardiovascular risk. N Engl J Med 2006; 354(14):1445-8.

11. Schelleman H, Bilker WB, Strom BL, et al. Cardiovascular events and death in children exposed and unexposed to ADHD agents. Pediatrics 2011; 127(6):1102-10.

12. Habel LA, Cooper WO, Sox CM,et al. ADHD medications and risk of serious cardiovascular events in young and middle-aged adults. JAMA 2011; 306(24):2673-83.

13. Antel J, Albayrak Ö, Heusch G, Banaschewski T, Hebebrand J. Assessment of potential cardiovascular risks of methylphenidate in comparison with sibutramine: do we need a SCOUT (trial)? Eur Arch Psychiatry Clin Neurosci 2015; 265:233-47.

14. Kelly AS, Rudser KD, Dengel DR, Kaufman CL, Reiff MI, Norris $\mathrm{AL}$, et al. Cardiac autonomic dysfunction and arterial stiffness among children and adolescents with attention deficit hyperactivity disorder treated with stimulants. J Pediatr 2014; 165:755-9.

15. Esler M, Kaye D. Measurement of sympathetic nervous system activity in heart failure: the role of norepinephrine kinetics. Heart Fail Rev 2000; 5(1):17-25.

16. Osadchii OE, Norton GR, McKechnie R, et al. Cardiac dilatation and pump dysfunction without intrinsic myocardial systolic failure following chronic beta-adrenoreceptor activation. Am J Physiol Heart Circ Physiol. 2007; 292(4):H1898-905.

17. Kaye DM, Smirk B, Finch S, et al. Interaction between cardiac sympathetic drive and heart rate in heart failure: modulation by adrenergic receptor genotype. J 
Am Coll Cardiol 2 004; 44(10):2008-15.

18. Regitz-Zagrosek V, Hocher B, Bettmann M, et al. Alpha2Cadrenoceptor polymorphism is associated with improved eventfree survival in patients with dilated cardiomyopathy. Eur Heart J 2006; 27(4):454-9.

19. Small KM, McGraw DW, Liggett SB. Pharmacology and physiology of human adrenergic receptor polymorphisms. Annu Rev Pharmacol Toxicol 2003; 43:381411.

20. Stein MA, Sarampote CS, Waldman ID, et al. A doseresponse study of OROS methylphenidate in children with attention-deficit/hyperactivity

disorder. Pediatrics 2003; 112(5):e404-413.

21. Take G, Bahcelioglu M, Oktem H, et al. Dose-dependent immunohistochemical and ultrastructural changes after oral methylphenidate administration in rat heart tissue. Anat Histol Embryol 2008;37(4):303-8.

22. Adler LA, Orman C, Starr HL, et al. Long-term safety of OROS methylphenidate in adults withattention-deficit/hyperactivity disorder: an open-label, dosetitration, 1-year study. J Clin Psychopharmacol 2011; 31(1):108-14. 